\title{
Front Matter: Volume 10053
}

, "Front Matter: Volume 10053," Proc. SPIE 10053, Optical Coherence Tomography and Coherence Domain Optical Methods in Biomedicine XXI, 1005301 (22 March 2017); doi: 10.1117/12.2270049

SPIE. Event: SPIE BiOS, 2017, San Francisco, California, United States 


\title{
Optical Coherence Tomography and Coherence Domain Optical Methods in Biomedicine XXI
}

\author{
James G. Fujimoto \\ Joseph A. Izatt \\ Valery V. Tuchin \\ Editors
}

29 January-1 February 2017

San Francisco, California, United States

Sponsored and Published by

SPIE 
The papers included in this volume were part of the technical conference cited on the cover and title page. Papers were selected and subject to review by the editors and conference program committee. Some conference presentations may not be available for publication. The papers published in these proceedings reflect the work and thoughts of the authors and are published herein as submitted. The publisher is not responsible for the validity of the information or for any outcomes resulting from reliance thereon.

Please use the following format to cite material from these proceedings:

Author(s), "Title of Paper," in Optical Coherence Tomography and Coherence Domain Optical Methods in Biomedicine XXI, edited by James G. Fujimoto, Joseph A. Izatt, Valery V. Tuchin, Proceedings of SPIE Vol. 10053 (SPIE, Bellingham, WA, 2017) Seven-digit Article CID Number.

ISSN: 1605-7422

ISSN: 2410-9045 (electronic)

ISBN: 9781510605473

ISBN: 9781510605480 (electronic)

Published by

SPIE

P.O. Box 10, Bellingham, Washington 98227-0010 USA

Telephone +1 3606763290 (Pacific Time) · Fax +1 3606471445

SPIE.org

Copyright (C) 2017, Society of Photo-Optical Instrumentation Engineers.

Copying of material in this book for internal or personal use, or for the internal or personal use of specific clients, beyond the fair use provisions granted by the U.S. Copyright Law is authorized by SPIE subject to payment of copying fees. The Transactional Reporting Service base fee for this volume is $\$ 18.00$ per article (or portion thereof), which should be paid directly to the Copyright Clearance Center (CCC), 222 Rosewood Drive, Danvers, MA 01923. Payment may also be made electronically through CCC Online at copyright.com. Other copying for republication, resale, advertising or promotion, or any form of systematic or multiple reproduction of any material in this book is prohibited except with permission in writing from the publisher. The CCC fee code is 1605 $7422 / 17 / \$ 18.00$.

Printed in the United States of America.

Publication of record for individual papers is online in the SPIE Digital Library.

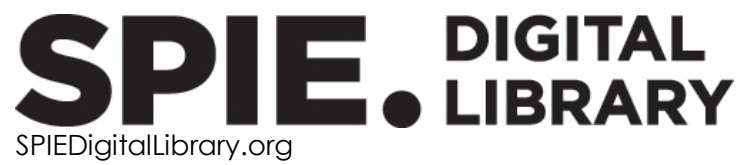

Paper Numbering: Proceedings of SPIE follow an e-First publication model, with papers published first online and then in print. Papers are published as they are submitted and meet publication criteria. A unique citation identifier (CID) number is assigned to each article at the time of the first publication. Utilization of CIDs allows articles to be fully citable as soon as they are published online, and connects the same identifier to all online, print, and electronic versions of the publication. SPIE uses a seven-digit CID article numbering system in which:

- The first five digits correspond to the SPIE volume number.

- The last two digits indicate publication order within the volume using a Base 36 numbering

system employing both numerals and letters. These two-number sets start with 00, 01, 02, 03, 04, $05,06,07,08,09,0 A, 0 B \ldots$. OZ, followed by 10-1Z, 20-2Z, etc.

The CID Number appears on each page of the manuscript. The complete citation is used on the first page, and an abbreviated version on subsequent pages. 


\title{
Contents
}

\author{
vii Authors \\ ix Conference Committee \\ xi Introduction
}

NEW OPHTHALMIC IMAGING TECHNOLOGY

1005305 Multimodal swept-source spectrally encoded scanning laser ophthalmoscopy and optical coherence tomography at $400 \mathrm{kHz}$ [10053-4]

\section{ENDOSCOPY/CARDIOLOGY}

10053 OB Design and optimization of a miniaturized imaging probe for simultaneous endomicroscopy and optical coherence tomography [10053-10]

\section{OPHTHALMOLOGY}

10053 ol Image-guided feedback for ophthalmic microsurgery using multimodal intraoperative swept-source spectrally encoded scanning laser ophthalmoscopy and optical coherence tomography [10053-17]

10053 OK Retinal imaging with adaptive optics full-field OCT [10053-19]

\section{NEW OCT TECHNOLOGY I}

$100530 Z$ 3D wide field-of-view Gabor-domain optical coherence microscopy advancing real-time in vivo imaging and metrology [10053-34]

\section{FUNCTIONAL OCT I}

1005317 Birefringence and vascular imaging of in vivo human skin by Jones-matrix optical coherence tomography [10053-42]

1005319 Correlation between polarization sensitive optical coherence tomography and SHG microscopy in articular cartilage [10053-44]

10053 1B Polarization-sensitive plug-in optical module for a Fourier-domain optical coherence tomography system [10053-46] 
10053 ID High sensitivity contrast enhanced optical coherence tomography for functional in vivo imaging [10053-48]

\section{CLINICAL APPLICATIONS}

$10053 \mathrm{iH} \quad$ Extracting relevant information for cancer diagnosis from dynamic full field OCT through image processing and learning [10053-52]

\section{NEW OCT TECHNOLOGY II}

1005310 Scattering angle resolved optical coherence tomography for in vivo murine retinal imaging [10053-59]

10053 IR Master/slave: the ideal tool for coherence revival based optical coherence tomography imaging instruments [10053-62]

\section{OCT WITH NEW LIGHT SOURCES}

10053 IT Analysis of FDML lasers with meter range coherence [10053-64]

10053 IW Ultralong-range optical coherence tomography-based angiography by akinetic swept source [10053-67]

\section{FUNCTIONAL OCT II}

$100531 \mathrm{Y}$ Non-contact rapid optical coherence elastography by high-speed 4D imaging of elastic waves [10053-69]

1005312 Line-field low coherence holography for ultra-fast assessment of tissue biomechanical properties [10053-70]

1005322 Model-independent quantification of soft tissue viscoelasticity with dynamic optical coherence elastography [10053-73]

1005324 Characterization of nonlinear elasticity for biological tissue using quantitative optical coherence elastography [10053-75]

\section{IMAGE AND SIGNAL PROCESSING}

1005326 Multi-volumetric registration and mosaicking using swept-source spectrally encoded scanning laser ophthalmoscopy and optical coherence tomography [10053-77]

1005329 Using speckle to measure tissue dispersion in optical coherence tomography [10053-80]

10053 2C A stochastically fully connected conditional random field framework for super resolution OCT [10053-83] 
$100532 \mathrm{D}$ High contrast and polarization-artifact-free optical coherence tomography by maximum a-posteriori estimation [10053-84]

POSTER SESSION: TECHNOLOGY AND IMAGE PROCESSING

$100532 \mathrm{G}$ Graphics processor unit acceleration enables realtime endovascular Doppler optical coherence tomography imaging [10053-87]

$100532 \mathrm{~L} \quad$ High frame-rate en face optical coherence tomography system using KTN optical beam deflector [10053-92]

10053 2M Compact LED-based full-field optical coherence microscopy for high-resolution highspeed in vivo imaging [10053-93]

10053 2N Dependence on fiber Fabry-Pérot tunable filter characteristics in an all-fiber sweptwavelength laser for use in an optical coherence tomography system [10053-94]

1005320 Speckle variance full-field optical coherence microscopy for high-resolution microvasculature mapping [10053-95]

$100532 \mathrm{P}$ Speckle variance optical coherence tomography using an SS-OCT system and an extended $k$-sampling clock [10053-96]

$100532 Q \quad$ Optimization of data processing with the Akinetic swept-laser: algorithm to automatically adjust the A-scan synchronization delay [10053-97]

10053 2R Contrast improvement for swept source optical coherence tomography image of subsurface tissue [10053-98]

POSTER SESSION: FUNCTIONAL AND APPLICATIONS

$100532 \mathrm{~W}$ Tissue dispersion measurement techniques using optical coherence tomography [10053-103]

$100532 \mathrm{X}$ Speckle reduction of OCT images using an adaptive cluster-based filtering [10053-104]

$100532 Z$ Dual-beam angular compounding for speckle reduction in optical coherence tomography [10053-106]

1005330 Optical coherence tomography with pre-calculated reference spectra [10053-107]

1005331 Volumetric vessel reconstruction method for absolute blood flow velocity measurement in Doppler OCT images [10053-108]

1005332 Coagulation monitoring based on blood elastic measurement using optical coherence tomography [10053-109]

1005334 Collagen birefringence assessment in heart chordae tendineae through PS-OCT [10053-111] 
1005335 Depth-encoded dual beam phase-resolved Doppler OCT for Doppler-angle-independent flow velocity measurement [10053-112]

1005336 Gold nanoparticles evaluation using functional optical coherence tomography [10053-113]

1005338 Rat brain imaging using full field optical coherence microscopy with short multimode fiber probe [10053-115]

10053 3C A novel dermo-epidermal localization algorithm for swept source OCT images of human skin [10053-120]

10053 3D Classification of human ovarian tissue using full field optical coherence tomography [10053-121]

10053 3F Textural analysis of optical coherence tomography skin images: quantitative differentiation between healthy and cancerous tissues [10053-123] 


\section{Authors}

Numbers in the index correspond to the last two digits of the seven-digit citation identifier (CID) article numbering system used in Proceedings of SPIE. The first five digits reflect the volume number. Base 36 numbering is employed for the last two digits and indicates the order of articles within the volume. Numbers start with 00, 01, 02, 03, 04, 05, 06, 07, 08, 09, OA, OB...0Z, followed by 10-12, 20-2Z, etc.

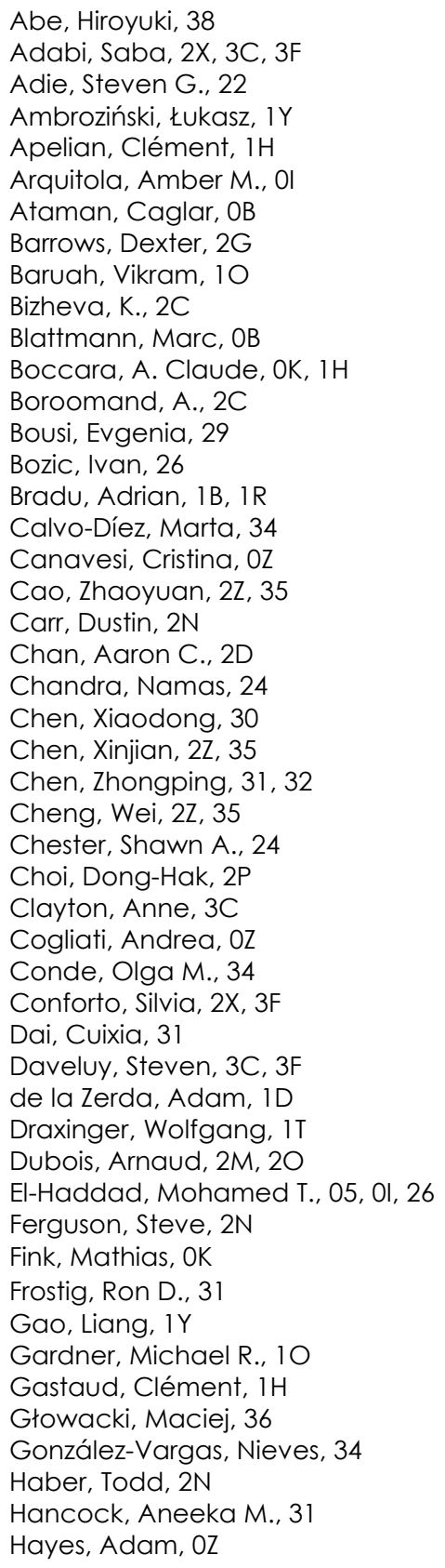

Hong, Young-Joo, 17, 2D

Hosseinzadeh, Matin, 3F

Huang, Lin, 19

Huber, Robert, $1 \mathrm{~T}$

Imai, Tadayuki, 2L

lyer, Rishyashring, 22

Jenkins, Robert, $2 \mathrm{~N}$

Jivraj, Jamil, 2G

Joos, Karen M., 05, 0l, 26

Ju, Myeong Jin, 19

Kamińska, Aleksandra, 36

Kasaragod, Deepa, 17

Katta, Nitesh, 10

Kawauchi, Satoko, 38

Khalil Abad, Adeleh Taghavi, 3C

Klein, Thomas, $1 \mathrm{~T}$

Kobayashi, Junya, 2L

Kretschmer, Simon, OB

Kurotani, Reiko, 38

Lamouche, Guy, 2Q

Larin, Kirill V., $1 \mathrm{Z}$

Leartprapun, Nichaluk, 22

Lee, Kenneth, 2G

Li, David, IY

Li, En, 17

Li, Jianwei D., Ol

Li, Xinyu, 2R

Liang, Haitao, 30

Liang, Shanshan, $2 R$

Liba, Orly, 1D

Liu, Chih-Hao, $1 \mathrm{Z}$

Liv, Xuan, 24

López-Higuera, José M., 34

Makita, Shuichi, 17, 2D

Malone, Joseph D., Ol, 26

Marques, Manuel J., 1B

McElroy, Austin, 10

Mehregan, Darius, 2X, 3F

Milner, Thomas E., 10

Miura, Masahiro, 2D

Mo, Jianhua, 2Z, 35

Mock, Joel, 2N

Nandy, Sreyankar, 3D

Nasiriavanaki, Mohammadreza, 2X, 3C, 3F

Nishidate, Izumi, 38

Noe, Shahryar, 3F

O'Donnell, Matthew, $1 Y$

Ogien, Jonas, $2 \mathrm{M}, 2 \mathrm{O}$

Ohbayashi, Kohji, 2P 
Ohmi, Masato, 2L

Patel, Shriji N., 05, 0l, 26

Zhang, Xuping, 31

Pelivanov, Ivan, $1 Y$

Zhou, Xin, 19

Petermann, Markus, $1 T$

Zhu, Jiang, 31, 32

Pfeiffer, Tom, $1 \mathrm{~T}$

Zhu, Quing, 3D

Photiou, Christos, 29, 2W

Zouvani, loanna, 29

Pitris, Costas, 29, 2W

Podoleanu, Adrian, 1B, 1R

Pontón, Alejandro, 34

Qi, Li, 31

Qian, Jie, 2Z, 35

Qiu, Yi, 24

Rashedi, Elaheh, $2 X$

Real, Eusebio, 34

Revuelta, José M., 34

Rivard, Maxime, $2 Q$

Rivet, Sylvain, 1B, IR

Rolland, Jannick P., $\mathrm{OZ}$

Rylander, H. Grady, III, 10

Saito, Daisuke, 38

Sakamoto, Tadashi, 2 L

Sanders, Melinda, 3D

Santhanam, Anand, $0 Z$

Sato, Manabu, 38

Sato, Shunichi, 38

Sawczak, Mirosław, 36

Schill, Alexander, $1 \mathrm{Z}$

Sen, Debasish, 1D

Shen, Tueng T., 1Y

Shinya, Yusuke, 2L

Singh, Manmohan, $1 \mathrm{Z}$

Soltanizadeh, Hadi, 3C

Song, Shaozhen, IW, IY

SoRelle, Elliott D., 1D

Stay, Justin L., 2N

Strakowski, Marcin R., 36

Tan, B., 2C

Tang, Shuo, 19

Tankam, Patrice, $\mathrm{OZ}$

Tao, Yuankai K., 05, Ol, 26

Toyoda, Seiji, 2L

Vilches, Sergio, OB

Vuong, Barry, 2G

Wang, Ruikang K., IW, IY

Wang, Yi, 30

Wieser, Wolfgang, $1 T$

Wong, A., 2C

Wu, Chen, $1 \mathrm{Z}$

Xiao, Peng, OK

$X U$, Jingjiang, $1 \mathrm{~W}$

$X u$, Qiuyun, 2X

$X u, X i a n g q u n, 32$

Yang, Victor X. D., $2 G$

Yasuno, Yoshiaki, 17, 2D

Yoon, Soon Joon, $1 Y$

Yoshimura, Reiko, 2P

Yu, Daoyin, 30

Zaki, Farzana R., 24

Zappe, Hans, OB

Zhang, Jun, $2 R$

viii

Proc. of SPIE Vol. $100531005301-8$ 


\title{
Conference Committee
}

\author{
Symposium Chairs
}

James G. Fujimoto, Massachusetts Institute of Technology

(United States)

R. Rox Anderson, Wellman Center for Photomedicine, Massachusetts General Hospital (United States) and Harvard Medical School

(United States)

Program Track Chairs

Tuan Vo Dinh, Fitzpatrick Institute for Photonics, Duke University (United States)

Anita Mahadevan-Jansen, Vanderbilt University (United States)

\section{Conference Chairs}

James G. Fujimoto, Massachusetts Institute of Technology (United States)

Joseph A. Izatt, Duke University (United States)

Valery V. Tuchin, N.G. Chernyshevsky Saratov National Research State University (Russian Federation), National Research Tomsk State University (Russian Federation) and Institute of Precision Mechanics and Control (Russian Federation)

\section{Conference Program Committee}

Peter E. Andersen, Technical University of Denmark (Denmark)

Kostadinka Bizheva, University of Waterloo (Canada)

Stephen A. Boppart, University of Illinois at Urbana-Champaign (United States)

Zhongping Chen, Beckman Laser Institute and Medical Clinic (United States)

Johannes de Boer, Vrije Universiteit Amsterdam (Netherlands)

Wolfgang Drexler, Medizinische Universität Wien (Austria)

Grigory V. Gelikonov, Institute of Applied Physics (Russian Federation)

Christoph K. Hitzenberger, Medizinische Universität Wien (Austria)

Robert A. Huber, Universität zu Lübeck (Germany)

Rainer A. Leitgeb, Medizinische Universität Wien (Austria)

Xingde Li, Johns Hopkins University (United States)

Yingtian Pan, Stony Brook University (United States)

Adrian Gh. Podoleanu, University of Kent (United Kingdom)

Andrew M. Rollins, Case Western Reserve University (United States)

Guillermo J. Tearney, Wellman Center for Photomedicine

(United States) 
Ruikang K. Wang, University of Washington (United States)

Maciej Wojtkowski, Nicolaus Copernicus University (Poland)

Yoshiaki Yasuno, University of Tsukuba (Japan)

\section{Session Chairs}

1 New Ophthalmic Imaging Technology

James G. Fujimoto, Massachusetts Institute of Technology

(United States)

2 Endoscopy/Cardiology

Xingde Li, Johns Hopkins University (United States)

3 Ophthalmology

Joseph A. Izatt, Duke University (United States)

4 Small Animal

Stephen A. Boppart, Beckman Institute for Advanced Science and Technology (United States)

5 New OCT Technology I

Christoph K. Hitzenberger, Medizinische Universität Wien (Austria)

6 Doppler and OCTA

Grigory V. Gelikonov, Institute of Applied Physics (Russian Federation)

7 Functional OCT I

Maciej Wojtkowski, Nicolaus Copernicus University (Poland)

8 Clinical Applications

Peter E. Andersen, Technical University of Denmark (Denmark)

9 New OCT Technology II

Adrian G. Podoleanu, University of Kent (United Kingdom)

10 OCT with New Light Sources

Yoshiaki Yasuno, University of Tsukuba (Japan)

11 Functional OCT II

Kostadinka Bizheva, University of Waterloo (Canada)

12 Image and Signal Processing

Valery V. Tuchin, N.G. Chernyshevsky Saratov National Research State University (Russian Federation), National Research Tomsk State University (Russian Federation) and Institute of Precision Mechanics and Control (Russian Federation) 


\section{Introduction}

These proceedings are from the Optical Coherence Tomography and Coherence Domain Optical Methods in Biomedicine XXI (Conference 10053), held Sunday-Wednesday 29 January-1 February 2017 at SPIE Photonics West in San Francisco, California. This year's conference featured 128 oral and poster presentations from leading national and international research groups.

Optical coherence tomography and other coherence domain optical methods and instruments are proved to be effective tools for noninvasive medical diagnostics and monitoring a wide spectrum of pathologies as well as fundamental biomedical research. The focus of this conference is on the physical and mathematical grounds of coherence domain methods, as well as presentation of innovative instrumentation and techniques and their applications in biomedical science and clinical practice.

The conference was organized into several sessions including: New Ophthalmic Imaging Technology, Endoscopy/Cardiology, Ophthalmology, Small Animal, New OCT Technology I and II, Doppler and OCTA, Functional OCT I and II, Clinical Applications, OCT with New Light Sources, Image and Signal Processing, and two poster sessions. A predominant fraction of the papers focused on optical coherence tomography-basic research, instrumentation and applications. In general, good discussions and many questions were characteristic for many sessions.

This year, significant advances were presented in the development of new OCT technologies (two sessions) with discussion of OCT novel and upgraded technologies (New Ophthalmic Imaging Technology, Endoscopy/Cardiology, and Doppler and OCTA sessions). Innovative hardware and software achievements were also presented (OCT with New Light Sources and Image and Signal Processing sessions). In many cases, innovative approaches were tested for biomedical applications to demonstrate their new facilities (Small Animal, Ophthalmology, Clinical Applications sessions, and two sessions on Functional OCT).

These high quality researchers presenting recent achievements in biological and clinical applications of OCT were a good addition to numerous OCT papers presented at the Clinical Conferences of BiOS. Many Conferences once again had special sessions on OCT, such as Photonics in Dermatology and Plastic Surgery (Skin Cancer III: Optical Microscopy and OCT, OCT Angiography, OCT); Therapeutics and Diagnostics in Urology (OCT/DOT); Optical Imaging, Therapeutics, and Advanced Technology in Head and Neck Surgery and Otolaryngology (OCT and Related Technologies for Middle and Inner Ear Imaging); Diagnostic and Therapeutic Applications of Light in Cardiology (Multimodality Imaging, Optical Coherence Tomography); Diagnosis and Treatment of Diseases in the Breast and Reproductive System III (Breast Cancer, 
Developmental Biology, and Cardiovascular Developmental Biology); Clinical and Translational Neurophotonics (Optical Spectroscopy and Tomography II and III); Endoscopic Microscopy XII (Optical Coherence Tomography); Optical Techniques in Pulmonary Medicine IV (Imaging Cillia, Mucus, and Airway Structure and Function, Increasing Clinical Utility with Custom Catheter Designs, and Novel Techniques for Pulmonary Imaging); Lasers in Dentistry XXIII (OCT in Dental Tissues and Early Caries Detection, OCT in Oral Tissues and Biofilm, NIR Imaging); Ophthalmic Technologies XXVII (Ocular Elastography, Ophthalmic Imaging: Small Animal Models, Ophthalmic Imaging: Structure and Function, Ocular Angiography and Blood Flow, Ophthalmic Imaging: Adaptive Optics, Ophthalmic Imaging: Technology, and Ocular Biometry, Vision Correction and Vision Assessment), and Neural Imaging and Sensing (OCT I and II).

The two poster sessions contained a total of 44 papers on the major topics mentioned above and were held Sunday, 29 January, POSTERS I: Technology and Image Processing, with 18 posters and Monday, 30 January, POSTERS II: Functional and Applications, with 26 posters.

On Sunday, 29 January, a half-day short course for engineers, scientists, and clinicians SC312 - Principles and Applications of Optical Coherence Tomography by James Fujimoto accompanied the conference.

All submissions were fully peer reviewed. Authors were requested to submit a 3page summary of their paper and the program committee evaluated the submissions for technical content and assigned a numerical score to each paper. The selection of the papers as oral presentations, posters, or non-acceptance was based upon the program committee score. We have had very positive feedback and a record number of submissions and attendees again this year.

Not all presented papers are published in this volume 10053; however, the Conference Program and this Introduction reflect the full range of topics discussed during this very successful meeting.

The conference chairs would like to thank the members of the technical program committee for their help in organizing the meeting. We sincerely appreciate the support of SPIE and the conference staff. Finally, we would like to thank all of the conference attendees and manuscript authors for their contributions and participation which helped to make this meeting a success. 